\title{
Deux mots pour chaque chose
}

\author{
Susanne de Lotbinière-Harwood
}

Je suis une traduction. Dans mon corps bilingue habitent au moins deux mots pour chaque chose. Si je dis lips je ne dis pas lèvres. A double sens de la tête au cul, je parle toujours beside myself.

Dans l'image rêvée mes lèvres se posent sur tes lips. Le jour se lève, je me réveille visitée par ta chaleur though you are far away (I do not know it). Le sang gonflé, je me retournerais t'envelopperais te goûterais. 'C'est si simple l'amour.' ${ }^{*}$ Comment dire chose si simple? On en rêve. But in which ... tongue?

The movies were never silent

- there was always a piano.

Lilian Gish, 1987

Il n'y a pas d'image muette. Dans l'espace d'une boucheà l'autrese pose la question de(s) langue(s). Nos levrres se parlent - laquelle? L'une ne bouge pas seule et ne saurait suffire poursignifier ce quia lieu entre elles.

'Fricatelle ruisselle essentielle aime-t-elle le long de son corps la morsure, le bruit des vagues, aime-t-elle l'état du monde dans la flambée des chairs pendant que les secondes s'écoulent cyprine, lutines, marines.'

Nicole Brossard, Sousla langue

A veil lifts an image speaks deeper than lips touching. What was un-seen yet known by the dreamer is now unveiled on condition she awaken, silken salty ... cyprine. 'No such word,' you say. L'anglais n'a pas de mot pour le dire. ${ }^{1}$ No word but wet,' you say. X-rated female

1. Editor's note: the word cyprine does not exist 'naturally' in French, i.e. in common usage or in the dictionary. It is a good example of a word put into circulation by feminist writers in the 70s, notably by Denise Boucher with her book Cyprine. GS 
desire. Like this body bilingual trying to voice in just one language at a time when only one tongue cannot speak what is taking place between them (elles). Yet the dream-text is written: read my ... lèvres. Si belle beauté au fond du bois de la nuit, dormante, s'éveille, c'est par l'amour. Elle dormait du sommeil de la pomme empoisonnée, elle s'éveille sur une bouche charmante. Du savoir viendra (-) au féminin.

Let us read, in a 'common language,' the inter-sextual dream we are wa(l)king into. Call it Aphrodite's foam, gynergic secretions, yoni juice. 'Fabriquons un mot pour (se) le dire,' redisent mes lèvres dilatées. And so, border woman ${ }^{* *}$ that she is, the translator deletes the e muet mutant, silent like the dream of two mouths meeting, and delivers the word 'cyprin' into the lexical gap of the English tongue. Fondue la place des deux solitudes, là où la lenteur fait du bien.

'Does she frictional she fluvial sheessential does she all along her body love the bite, the sound waves, does shelove thestate of the world in the blaze of flesh to flesh as seconds flow by silken salty cyprin.'

\section{Brossard, Under Tongue}

Double de la tête au cul, je suis une trahison. Je pense en français $j$ 'aime en anglais. Je trompe ma-maman lalalangue of love. Je suis le scandale du corps bilingue, l'irrecevable l'a-syntaxiquel'impossibleà topographier.

Au réveilles sens prennent la parole. Alors se dévoile cequeseule la dormante savait, avant: ce qui a lieu entre elles: du désir d'une langue commune. Rêver traduire dans le réel l'image muette de mes lèvres sur tes lips, c'est désirer parler mon corps bilingue dans deuxlangues-en-une sans espace(entre) qui déçoive deux fois lesens. Or de cette parole il faut savoir qu'elle n'a pas lieu.

Elle -

elle donne lieu, à.

Non. She -

takes place.

No, it's more like:

she makes (her) place.

Elle fait lieu

de deux. 


$$
\text { 26. Tessera }
$$

Texte-source / context:

Nicole Brossard, Sous la langue / Under Tongue. Traduit par Susanne de Lotbinière-Harwood. L'Essentielle, éditrices / Gynergy Books, Montréal / Charlottetown, 1987.

Textes de soutien / Resonance pieces:

* Arletty, dans Les Enfants du paradis, Marcel Carné, 1945.

Luce Irigaray, Et l'une ne bouge pas sans l'autre, Ed Minuit, 1979.

** Gloria Anzaldua, Borderlands / La Frontera: The New Mestiza, Spinsters / Aunt Lute, San Francisco, 1987.

Gail Scott, Heroine, Coach House, Toronto, 1987. Héroine, traduit par S. de L.Harwood, Editions de remue-ménage, Montréal, 1988. 